\title{
Penerapan E-Learning dengan Aplikasi Zenius untuk Meningkatkan Motivasi Belajar Siswa SMP Negeri 2 Kampar Utara
}

\author{
Nurfitriana $^{1}$, Zulfah $^{2}$ \\ ${ }^{1,2}$ Prodi Pendidikan Matematika, Fakultas Ilmu Pendidikan, Universitas Pahlawan Tuanku Tambusai, Riau \\ Jl. Tuanku Tambusai No 23 Bangkinang, Riau, Indonesia \\ zulfahasni670@gmail.com
}

\begin{abstract}
This Classroom Action Research aims to increase learning motivation and mastery of E-learning by using the Zenius application in class VIII students of SMP Negeri 2 Kampar Utara in the academic year 2019/2020, totaling 32 people. This research was conducted from the beginning of April 2020 until the end of April 2020. This research is a classroom action research conducted online using several questionnaires, the link of which is sent to students through their WhatsApp group. This online research was conducted because it did not allow the writer to conduct research directly to school because at this time the teaching and learning process was carried out online. This online learning is due to the spread of the COVID-19 corona virus in almost all countries including Indonesia.
\end{abstract}

Keywords: Learning Motivation, E-learning, Zenius, Pandemic, Covid-19.

\begin{abstract}
Abstrak
Penelitian Tindakan Kelas ini bertujuan untuk meningkatkan motivasi Belajar dan penguasaan E-learning dengan menggunakan aplikasi Zenius pada siswa kelas VIII SMP Negeri 2 Kampar Utara tahun ajaran 2019/2020, yang berjumlah 32 orang. Penelitian ini dilakukan pada tanggal awal April 2020 sampai akhir April 2020. Penelitian ini merupakan penelitian tindakan kelas yang dilakukan secara online dengan menggunakan beberapa kuesioner yang linknya dikirim kepada siswa melalui group whatsaap yang dimilikinya. Penelitian online ini dilakukan karena tidak memingkinkan penulis melakukan penelitian secara lagsung kesekolah karena pada saat ini proses belajar mengajar dilakukan secara online (daring). Pembelajaran daring ini disebabkan karena adanya penyebaran virus korona COVID-19 hampir diseluruh Negara termasuk Indonesia.
\end{abstract}

Kata Kunci : Motivasi Belajar, E-learning, Zenius, Pandemi, Covid-19

Copyright (c) 2020 Nurfitriana, Zulfah

$\triangle$ Corresponding author: zulfahasni670@gmail.com

Email Address: zulfahasni670@gmail.com

Received 29 November 2020, Accepted 05 Desember 2020, Published 09 Desember 2020

\section{PENDAHULUAN}

Mewabahnya virus Corona membuat beberapa pemerintah daerah mulai mengambil sikap untuk meliburkan sekolah sebagai suatu upaya untuk mencegah sekaligus mengurangi penyebaran virus Corona. Kegiatan akademik selama masa ini banyak dilakukan melalui belajar dari rumah (study from home). Tak sedikit pula dari instansi pendidikan yang memberlakukan E-learning atau kelas online untuk melakukan proses belajar mengajar jarak jauh.. Pada dasarnya E-learning merupakan suatu sistem atau konsep pendidikan yang memanfaatkan teknologi informasi dalam proses belajar mengajar. Menerapkan E-learning di tengah situasi virus Corona bukan saja bermanfaat untuk melindungi para siswa dari penyebaran virus Corona, melainkan menerapkan E-learning juga bisa membangun rasa percaya diri dan kemandirian dari para siswa. Selain itu, keunggulan sistem Elearning lainnya yaitu menghemat waktu proses belajar mengajar, mengurangi biaya perjalanan, 
Penerapan E-Learning dengan Aplikasi Zenius untuk Meningkatkan Motivasi Belajar Siswa SMP Negeri 2 Kampar

menghemat biaya pendidikan secara keseluruhan baik berupa biaya infrastruktur, peralatan sekolah dan buku sekolah, dan menjangkau wilayah geografis yang jauh lebih luas.

Berdasarkan kondisi diatas, peneliti akan mengkaji bagaimana peningkatan motivasi belajar siswa dengan menggunakan penerapan media E-Learning yaitu Zenius pada Pembelajaran Matematika di kelas VIII SMP Negeri 2 Kampar Utara selama larangan pembelajaran tatap muka di temgah Pandemi Covid-19 sekaligus menerapkan pembelajaran E-learning pada pembelajaran Matematika.

\section{METODE}

Penelitian yang mengkaji Penerapan E-Learning dengan Aplikasi Zenius Untuk Meningkatkan Motivasi Belajar Siswa SMP Negeri 2 Kampar Utara ini berlokasikan di Jalan Pematang Kulim Km 54 Desa Muara Jalai Kabupaten Kampar. Penelitian ini dilakukan selama kurang lebih dari 2 bulan lamanya. Penelitian ini dilaksanakan pada awal bulan April 2020 sampai Mei 2020.

Penelitian ini merupakan penelitian tindakan kelas yang dilakukan secara online dengan menggunakan beberapa kuesioner yang linknya dikirim kepada siswa melalui group whatsaap yang dimilikinya. Penelitian online ini dilakukan karena tidak memingkinkan penulis melakukan penelitian secara lagsung kesekolah karena pada saat ini proses belajar mengajar dilakukan secara online (Daring). Pembelajaran daring ini disebabkan karena adanya penyebaran virus korona COVID-19 hampir diseluruh Negara termasuk Indonesia.

Penelitian ini membutuhkan subyek yang akan diteliti agar mampu menjawab pertanyaan penelitian yang disiapkan oleh peneliti dan tentunya yang terkait dengan fokus peneliti. Adapun subyek dalam penelitian ini yaitu, siswa. Intrumen pengumpulan data yang didapat yaitu dengan menggunakan wawancara. Wawancara digunakan sebagai teknik pengumpulan data apabila peneliti ingin melakukan studi pendahuluan untuk menemukan permasalahan yang harus diteliti, dan juga apabila peneliti ingin mengetahui hal-hal dari responden yang lebih mendalam dan jumlah respondennya sedikit/kecil. Teknik pengumpulan data ini dilakukan dengan cara memberikan beberapa questioner yang dirancang dengan menggunakan google form yang linknya dikirimkan kepada siswa kelas VIII SMP Negeri 2 Kampar Utara Tahun Ajaran 2019/2020 yang berjumlah 32 orang.

Sebelum semua data diperoleh, instrument yang ada harus dkoreksi terlebih dahulu. Pengoreksian instrument yaitu berupa Quesioner yaitu dilakukan dengan memperhatikan arahan dan masukan dari dosen pembimbing, validitas logis. Berhubungan dengan keterbatasan waktu, instrument tersebut akan divalidasi juga secara logis. Setelah instrumen berupa questioner sudah benar dan dikirim kepada siswa, data yang diperoleh akan dianalisis. Adapun teknik analisis data yang dilakukan peneliti adalah Analais Data Hasil Quesioner. Setelah peneliti memastikan bahwa siswa menjawab questioner yang sebelumnya sudah dipastikan benar, peneliti akan melihat informasi dari 
masing-masing responden. Peneliti akan melihat berapa banyak siswa merespon dan bagaimana jawabannya.

Penelitian yang berjudul Penerapan E-learning dengan Aplikasi Zenius untuk Meningkatkan Motivasi Siswa SMP 2 Kampar Utara ini, siswa diharapkan dapat termotivasi untuk melakukan pembelajaran khususnya belajar matematika. Siwa diharapkan dapat menguasai materi matematika melalui pembelajaran online yang dilaksakannya. Pada penelitian ini tentunya siswa sudah mengetahui apa itu E-lerning dan bagaimana prosesnya.

Para ahli mendefinisikan e-learning sesuai dengan sudut pandangnya. Karena e-learning kepanjangan dari electronic learning. Ada yang menafsirkan e-learninng sebagi bentuk pembelajaran yang memanfaatkan teknologi (radio, televisi, film, komputer, internet, dlll). Jaya Kumar C. Koran mendefinisikan e-learning sebagai sembarang pengajaran dan pembelajaran yang menggunakan rangkaian elektronik (LAN, WAN, atau internet) untuk menyampaikan isi pembelajaran, interaksi atau bimbingan.

Rosenberg menekankan bahwa e-learning merujuk pada penggunaan teknologi internet untuk mengirimkan serangkaian solusi yang dapat meningkatkan pengetahuan dan keterampilan. Hal ini senada dengan Cambell yang intinya menekankan penggunaan internet dalam pendidikan sebagai hakikat e-learning (Isjoni dkk, 2008). Onno menjelaskan bahwa istilah "E" atau singkatan dari elektronik dalam e-learning digunakan sebagai istilah untuk segala teknologi yang digunakan untuk mendukung usaha-usaha pengajaran lewat teknologi internet.

Di tengah Pandemi Covid-19 ini guru disekolah banyak dianjurkan untuk menggunakan google calssrom sebagai ganti tatap muka. Tetapi pada peneltian kali ini peneliti menggunakan applikasi zenius untuk meningkatkan motivasi belajar siswa. Dan pada penelitian ini siswa di harapkan termotivasi mengikuti pembelajaran matematika melalui aplikasi Zenius yang didalamnya terdapat vodeo penjelasan mengenai meteri yang akan dipelajari.

Motivasi adalah usaha yang didasari untuk mengerahkan dan menjaga tingkah seseorang agar ia terdorong untuk bertindak melakukan sesuatu sehingga mencapai hasil atau tujuan tertentu. Motivasi belajar adalah suatu perubahan tenaga di dalam diri seseorang (pribadi) yang ditandai dengan timbulnya perasaan dan reaksi untuk mencapai tujuan (Frederick J.Mc.Donald dalam $\mathrm{H}$ Nashar, 2004:39). Tetapi menurut Clayton Aldelfer dalam H.Nashar (2004:42) motivasi belajar adalah kecenderungan siswa dalam melakuka kegiatan belajar yang didorong oleh hasrat untuk mencapai prestasi hasil belajar sebaik mungkin.

Motivasi memegang peranan yang penting dalam proses belajar. Apabila guru dan orang tua dapat memberikan motivasi yang baik pada siswa atau anaknya, maka dalam diri siswa atau anak akan timbul dorongan dan hasrat untuk belajar lebih baik. Memberikan motivasi yang baik dan sesuai, maka anak dapat menyadari akan manfaat belajar dan tujuan yang hendak dicapai dengan belajar tersebut. Motivasi belajar juga diharapkan mampu menggugah semangat belajar, terutama bagi para siswa yang malas belajar sebagai akibat pengaruh negative dari luar diri siswa.Berdasarkan definisi- 
Penerapan E-Learning dengan Aplikasi Zenius untuk Meningkatkan Motivasi Belajar Siswa SMP Negeri 2 Kampar

definisi para ahli, maka motivasi belajar adalah dorongan atau hasrat kemauan untuk melaksanakan kegiatan belajar dalam rangka mencapai tujuan. Untuk memancing dan mencapai tujuan tersebut, peneliti melakukan penelitian dengan menggunakan aplikasi Zenius.

Zenius adalah sebuah website belajar online yang disediakan bagi siswa-siswi mulai dari kelas I SD sampai dengan kelas XII SMA/SMK/MA diseluruh Indonesia untuk belajar memahami materi sekolah, latihan soal, serta mengevaluasi pembahasan soal untuk 11 mata pelajaran yang sesui dengan kurikulum KTSP, Kurikulum 13, dan Kurikulum 13 Revisi. Zenius juga dilengkapi dengan persiapan Ujian Nasional (USBN + UNBK), SBMPTN, dan Ujian Mandiri masuk Perguruan Tinggi.

Secara garis besar, produk zenius dibagi menjadi 3, yaitu:

a) Website Zenius, yang berisi video pembelajaran, paket latihan soal yang bisa didownload gratis, mencakup seluruh materi pelajaran SD, SMP, SMA, pembahasan soal Ujian Nasional (tingkat SD-SMA), SBMPTN, dan berbagai Ujian Saringan Mandiri masuk PTN.

b) Zenius App, aplikasi belajar online berbasis Android. Berisi video pembelajaran, paket latihan soal yang bisa didownload gratis, serta latihan soal interaktif untuk menguji kemampuan dan pemahaman kamu.

c) Zenius Prestasi, adalah produk yang dirancang khusus untuk guru dan sekolah yang dapat dipasang pada jaringan lokal sekolah. Zenius Prestasi berisi aplikasi yang memudahkan guru untuk merancang proses ujian dengan sangat praktis. Dari proses pembuatan soal, pelaksanaan ujian CBT, proses koreksi, dan proses evaluasi semua bisa di-otomasi secara digital. Selain itu, Zenius Prestasi juga menyediakan ribuan video pembahasan materi pelajaran sekolah yang telah disesuaikan dengan 3 varian kurikulum Indonesia.

Dengan adanya aplikasi garatis ini memudahkan siswa untuk mengikuti pembelajaran matematika tanpa adanyanya pembayaran dari aplikasi. Siswa dapat melihat fitur berupa video terkait materi pembelajaran yang akan dipelajari. Dengan adanya aplikasi ini peneliti berharap siswa dapat memahami materi matematika dengan mudah dan meningkatkan antusiasnya dalam belajar matematika.

\section{HASIL DAN PEMBAHASAN}

Penelitian ini dilaksanakan di SMP Negeri 2 Kampar Utara dengan subjek penelitian siswa kelas VIII yang berjumlah 32 orang. sebelum penelitian dilaksakan, peneliti melakukan wawancara kepada guru mengenai bagaimana proses pembelajaran yang dilakukan siswa selama pandemi Covid19 dan meminta kerjasamanya untuk melakukan penelitian secara online. Setelah meminta persetujuan dari pihak sekolah, peneliti melakukan wawancara kepada siswa menggunakan google form dengan mengirimkan linknya kepada siswa melalui group whatsaap yang dimiliki siswa.

Penelitian ini berjudul Penerapan E-learning dengan Aplikasi Zenius untuk Meningkatkan Motivasi Belajar Siswa SMP 2 Kampar Utara. Dengan penelitian ini siswa diharapkan dapat termotivasi untuk melakukan pembelajaran khususnya belajar matematika. Siwa diharapkan dapat 
menguasai materi matematika melalui pembelajaran online yang dilaksakannya. Pada penelitian ini tentunya siswa sudah mengetahui apa itu E-lerning dan bagaimana prosesnya.

Penelitian ini dilaksanakan pada awal bulan April 2020 sampai Mei 2020. Pada penelitian ini siswa diharapkan dapat menjawab questioner yang linknya sudah dikirim melalui group whatsapp yang dimiliki siswa. Penelitian online ini dilakukan karena tidak memingkinkan penulis melakukan penelitian secara lagsung kesekolah karena pada saat ini proses belajar mengajar dilakukan secara online (Daring). Pembelajaran daring ini disebabkan karena adanya penyebaran virus korona COVID-19 hampir diseluruh Negara termasuk Indonesia.

Wawancara digunakan sebagai teknik pengumpulan data apabila peneliti ingin melakukan studi pendahuluan untuk menemukan permasalahan yang harus diteliti, dan juga apabila peneliti ingin mengetahui hal-hal dari responden yang lebih mendalam dan jumlah respondennya sedikit/kecil. Teknik pengumpulan data ini dilakukan dengan cara memberikan beberapa questioner yang dirancang dengan menggunakan google form yang linknya dikirimkan kepada siswa kelas VIII SMP Negeri 2 Kampar Utara Tahun Ajaran 2019/2020 yang berjumlah 32 orang.

Sebelum semua data diperoleh, instrument yang ada harus dkoreksi terlebih dahulu. Pengoreksian instrument yaitu berupa Quesioner yaitu dilakukan dengan memperhatikan arahan dan masukan dari dosen pembimbing, validitas logis. Berhubungan dengan keterbatasan waktu, instrument tersebut akan divalidasi juga secara logis. Setelah instrumen berupa questioner sudah benar dan dikirim kepada siswa, data yang diperoleh akan dianalisis. Adapun teknik analisis data yang dilakukan peneliti adalah Analais Data Hasil Quesioner. Setelah peneliti memastikan bahwa siswa menjawab questioner yang sebelumnya sudah dipastikan benar, peneliti akan melihat informasi dari masing-masing responden. Peneliti akan melihat berapa banyak siswa merespon dan bagaimana jawabannya. Adapun bentuk quesioner tersebut adalah sebagai berikut:

a) Jenis kelamin

- Pria

- Wanita

b) Nama lengkap

c) Nama sekolah

d) Alamat

e) Pendapat saudara mengenai Covid-19 yang terjadi saat ini

f) Dampak Covid-19 dalam dunia pendidikan saat ini

g) Apakah sekolah anda melaksanakan pembelajaran dari rumah semasa kovid-19?

- Ya

- Tidak

h) Metode pembelajaran yang digunakan selama masa pandemi Covid-19 
Penerapan E-Learning dengan Aplikasi Zenius untuk Meningkatkan Motivasi Belajar Siswa SMP Negeri 2 Kampar

- Daring (pembelajaran dalam jaringan computer/belajar online (online learning)/tegnologi lainnya)

- Luring (pembelajaran tanpa jaringan computer/tidak belajar online). Jika luring isi metodenya.(contoh belajar melalui buku paket, LKS, dll)

i) Perangkat/alat yang digunakan dalam mengikuti pembelajaran secara online (daring)

- Leptop

- Notebook

- Tablet

- Handphon

- Lainnya, sebutkan

j) Koneksi internet yang saudara gunakan

- Wifi

- Internet HP

- Tethering HP sejawat (Hospot)

- Lainnya, sebutkan

k) Model interaksi pembelajaran daring (pembelajaran online) yang digunakan guru

- Tatap muka interaktif langsung (Webex, Zoom, Skype, Webinar, dll.)

- Non- tatap muka dengan media social (Whatsapp, Line, Telegram, Messanger, dll)

- Campuran (tatap muka dan non tatap muka)

- Lainnya, sebutkan

1) Sebutkan aplikasi pembelajaran daring yang digunakan

- VClass

- Google Class

- Webinar

- Zoom

- Skype

- Webex

- whatsapp

- Facebook Live

- Youtube Live

- Lainnya, sebutkan

m) Seberapa siap fasilitas internet dalam pembelajaran online yang anda laksanakan selama pandemi Covid-19?

- Sangat Siap - internet cepat dan kuota cukup

- Siap - internet cepat 
- Siap - kuota cukup

- Kurang Siap - jaringan internet kurang stabil (lelet)

- Kurang siap - kuota idak mencukupi

- Kurang siap - jaringan internet kurang stabil dan kuota tidak mencukupi

n) Seberapa siap saudara belajar daring (belajar online)

- Sangat Siap

- Siap

- Kurang Siap

- Tidak siap

- $\quad$ Tidak Tahu

- Lainnya:

o) Seberapa baik saudara memahami materi pembelajaran daring (pembelajaran online) selama pandemi Covid-19?

- Sangat Baik

- Baik

- Sedang

- $\quad$ Kurang

- Sangat Kurang

- Lainnya :

p) Seberapa baik guru menyampaikan materi pembelajaran secara online?

- Sangat Baik

- Baik

- Sedang

- $\quad$ Kurang

- Sangat Kurang

q) Dengan diterapkannya pembelajaran secara online, saya dapat belajar dan mengerjakan tugas dengan baik

- Sangat Setuju

- Setuju

- Tidak Setuju

- Sangat Tidak Setuju

r) Saya lebih menyukai pembelajaran online (daring) dari pada pembelajaran dikelas

- Sangat Setuju

- Setuju

- Tidak Setuju 
Penerapan E-Learning dengan Aplikasi Zenius untuk Meningkatkan Motivasi Belajar Siswa SMP Negeri 2 Kampar

- Sangat Tidak Setuju

s) Pembelajaran Matematika lebih mudah saya pahami dengan menggunakan pembelajaran secara online (daring)

- Sangat Setuju

- Setuju

- $\quad$ Tidak Setuju

- Sangat Tidak Setuju

t) Seberapa baik kualitas penyajian materi matematika dalam pembelajaran online (info grafis, gambar, animasi, video, dll) dari guru?

- Sangat Baik

- Baik

- Sedang

- Kurang

- Sangat Kurang

- Lainnya:

u) Menurut anda apa saja keunggulan pembelajaran secara online (daring)?

(boleh lebih dari satu pilihan)

- Tidak perlu kesekolah

- Lebih mudah dan santai

- Pengalaman Baru

- Materi terdokumentasi dan dapat dipelajari kembali

- Lebih berani bertanya dan mengajak diskusi

- Lainnya, sebutkan

v) Menurut anda apa saja kekurangan pembelajaran online (daring)?

(boleh lebih dari satu pilihan)

- Jaringan internet kadang tidak stabil

- Sering diganti tugas online

- Konsentrasi kadang menurun

- Beban tugas yang berlebihan

- Guru kurang aktif dan komunikatif (sulit dihubungi)

w) Menurut saudara lebih baik menggunakan pembelajaran online (daring) dari atau pembelajaran tatap muka dikelas.

- Pembelajaran daring

- Pembelajaran tatap muka dikelas 
Sebelum semua data diperoleh, instrument berupa pertanyaan diatas sudah dikoreksi terlebih dahulu. Pengoreksian dilakukan dengan memperhatikan arahan dan masukan dari dosen pembimbing. Setelah instrumen berupa questioner sudah benar dan dikirim kepada siswa, data yang diperoleh akan dianalisis. Adapun teknik analisis data yang dilakukan peneliti adalah Analais Data Hasil Quesioner. Setelah peneliti memastikan bahwa siswa menjawab questioner yang sebelumnya sudah dipastikan benar, peneliti akan melihat informasi dari masing-masing responden. Peneliti akan melihat berapa banyak siswa merespon dan bagaimana jawabannya. Dibawah ini terdapat bentuk google form yang dikirim kepada siswa.
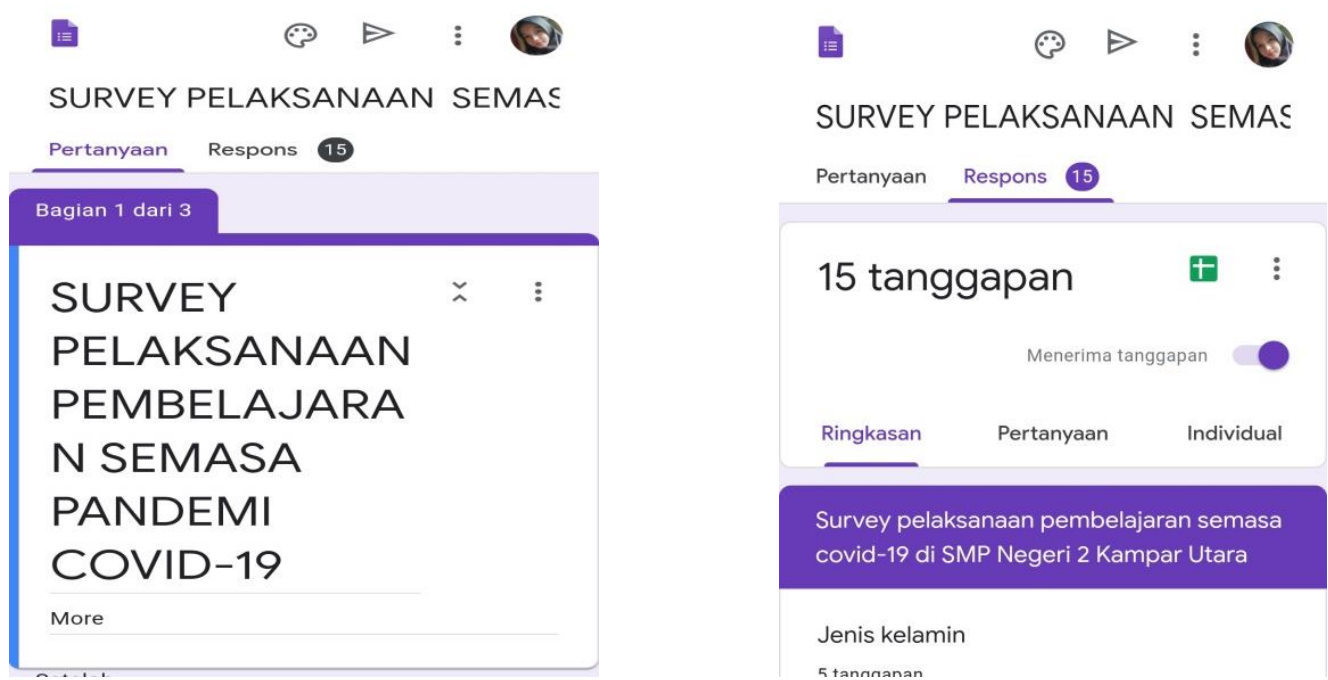

Gambar 1. Cuplikan Google Form yang Dikirim Kepada Siswa

Dari hasil analisis data hasil quesioner tersebut didapatkan 15 responden dari 32 siswa. Dari banyaknya siwa yang tidak merespon, peneliti tetap melanjutkan penelitian dari 15 responden tersebut. Peneliti mendapatkan hasil dari jawaban responden mengenai pembelajaran daring yang dilaksakan siswa yang ditetapkan disekolah. Dari banyaknya pertanyaan yang diajukan siswa, ,peneliti mendapatkan hasil bahwasanya ada siswa yang kurang siap melakukan pembelajaran dari rumah. Dari hasil quesioner, siswa kurang siap melakukan pembelajaran dirumah (daring) karena kurang baiknya guru dalam neyampaikan pembelajaran dan siswa tidak dapat belajar dan mengerjakan tugas dengan baik. Hal tersebut terjadi karena kurangnya penyajian materi dalam pembelajaran online khususnya pembelajaran matematika. Dari kendala tersebut dapat disimpulkan bahwa siswa kurang termotivasi untuk belajar matematika secara online. Adapun respon siswa terkait pembelajaran Matematika pada quesioner yang diberikan terdapat pada gambar dibawah ini. 
Penerapan E-Learning dengan Aplikasi Zenius untuk Meningkatkan Motivasi Belajar Siswa SMP Negeri 2 Kampar

Dengan diterapkannya

pembelajaran secara online, saya

dapat belajar dan mengerjakan

tugas dengan baik

12 tanggapan

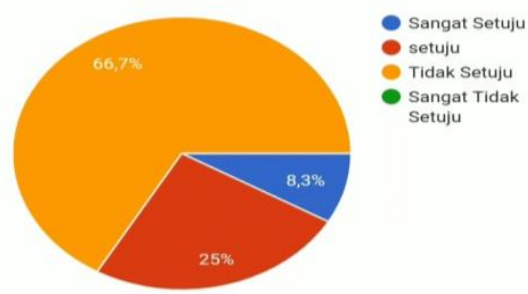

Gambar 2. Respon Siswa Terkait Pembelajaran Matematika Secara Daring
Pembelajaran Matematika lebih mudah saya pahami dengan online (daring)

12 tanggapan

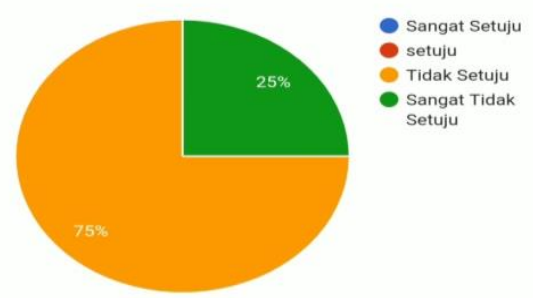
menggunakan pembelajaran secara

Dari data tersebut, penelitipun mencari solusi dengan menggunakan aplikasi zenius. Peneliti berpendapat bahwa dengan aplikasi ini siswa akan termotivasi untuk belajar matematika dari materimateri yang disajikan Zenius dalam bentuk video. Dengan adanya penyajian materi dalam bentuk video siswa akan lebih memahami materi dan dapat mengerjakan tugas-tugas yang diberikan guru melalui group whatsaap yg dimilkinya. Sebelum peneliti melakukan penelitian dengan aplikasi zenius, peneliti terlebih dahulu mengobservasi hasil dari latihan atau tugas harian mata pelajaran matematika dan masalah apa yang dihadapi siswa dalam pembelajaran matematika. Hal ini dilakukan untuk melihat perbandingan guna melihat peningkatan siswa dalam belajar matematika sebelum dan sesudah menggunakan aplikasi Zenius tersebut. Setelah itu, peneliti membimbing siswa untuk menggunakan aplikasi zenius. Pada aplikasi Zenius siswa terlebih dahulu mendaftarkan diri dengan menggunakan email dan meriset pasword untuk memasuki aplikasi Zenius. Setelah itu siswa dapat menggunakan aplikasi Zenius dengan mudah dan bebas akses. Adapun bentuk dari aplikasi zenius terdapat pada gambar dibawah ini.
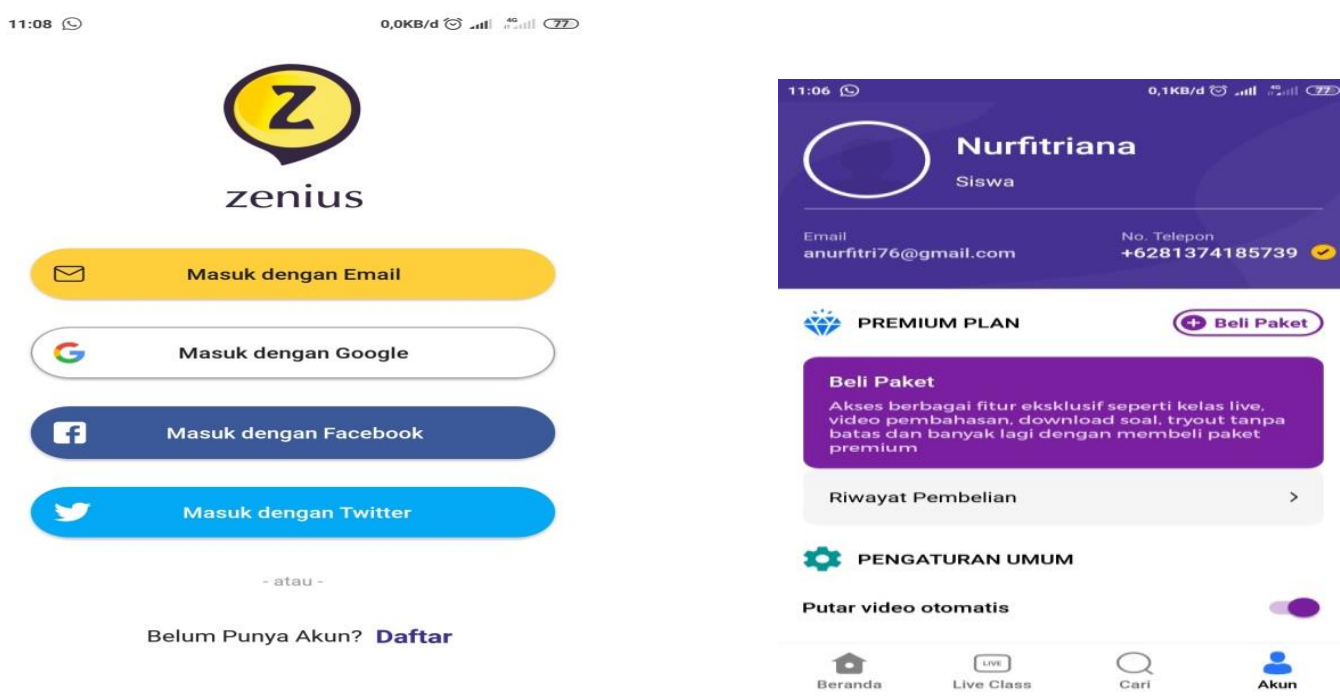

Gambar 3. Cuplikan Beranda Aplikasi Zenius 
Setelah siswa telah terdaftar seperti gambar 3, siswa dapat memilih mata pelajaran yang akan dipelajari seperti gambar dibawah ini.

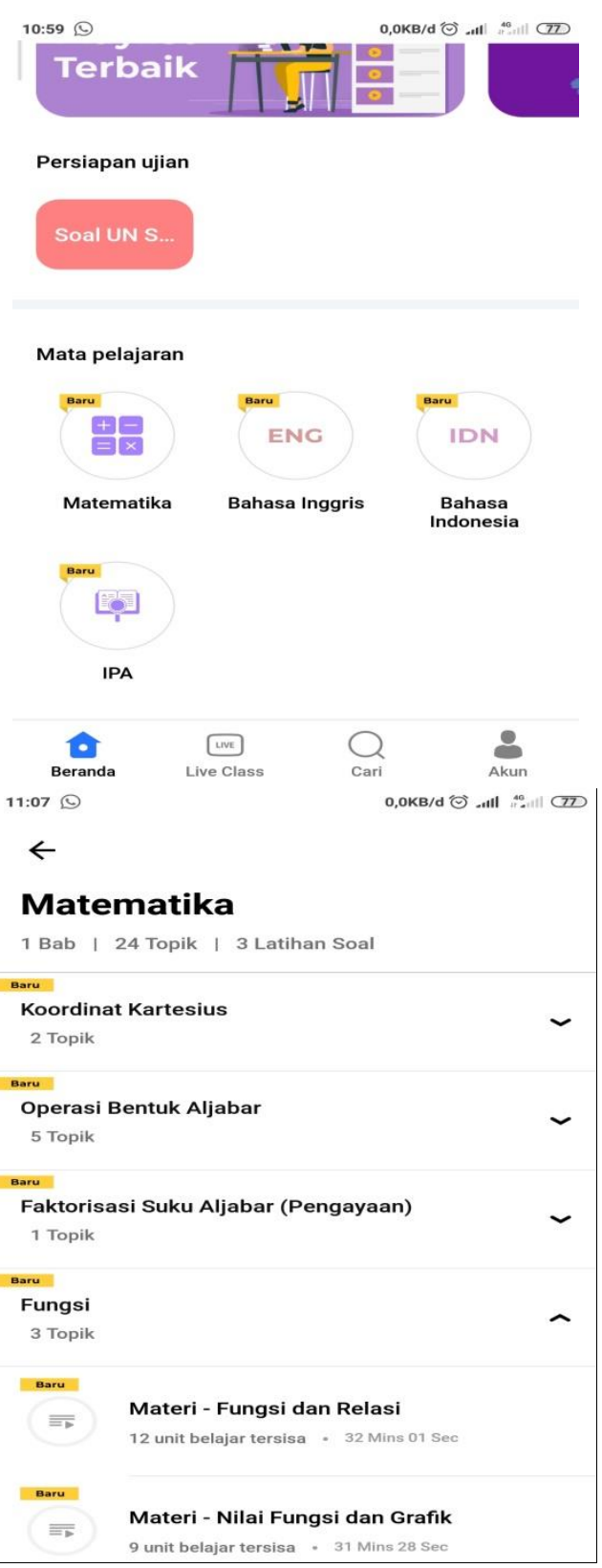

Gambar 4. Penyajian Materi Pada Aplikasi Zenius

Setelah siswa memilih salah satu materi yang akan dipelajari, siswa dapat melihat tayangan video dari materi pelajaran matematika tersebut. Setelah memahami materi tersebut siswa diharapkan dapat mengerjakan latihan soal yang disajikan dari tiap-tiap materinya guna untuk melihat perkembangan siswa dalam mengerjakan tugas-tugas latihan. Dengan adanya latihan soal tersebut siswa diharapkan dapat engerjakan tugas-tugas harian yang dikirimkan guru melalui group whatsaap yang mereka gunakan. Setelah tugas tersebut dikerjakan siswa disuruh untuk mengantarkan tugas yag dikerjakan kepada guru yang bersangkutan sesuai dengan jadwal disekolah. Setelah guru memeriksa 
Penerapan E-Learning dengan Aplikasi Zenius untuk Meningkatkan Motivasi Belajar Siswa SMP Negeri 2 Kampar Utara, Nurfitriana, Zulfah

tugas tersebut, peneliti akan melakukan observasi ulang mengenai hasil atau nilai yang didapat siswa setelah menggunakan aplikasi Zenius untuk memahami materi yang akan dipelajari siwa secara online teersebut. Dibawah ini akan disajikan perbandingan hasil tugas harian matematika siswa sebelum dan sesudah menggunakan aplikasi Zenius tersebut.

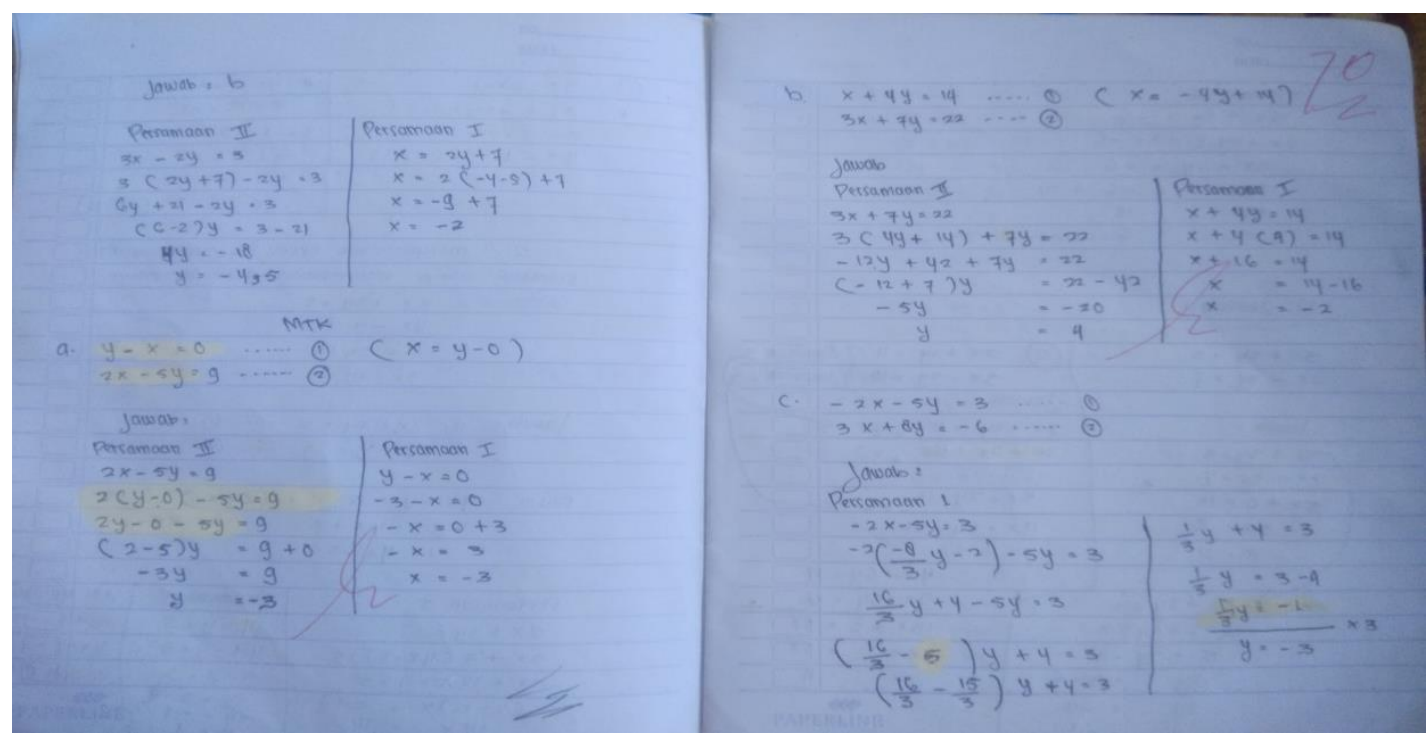

Gambar 5. Sebelum Menggunakan Zenius

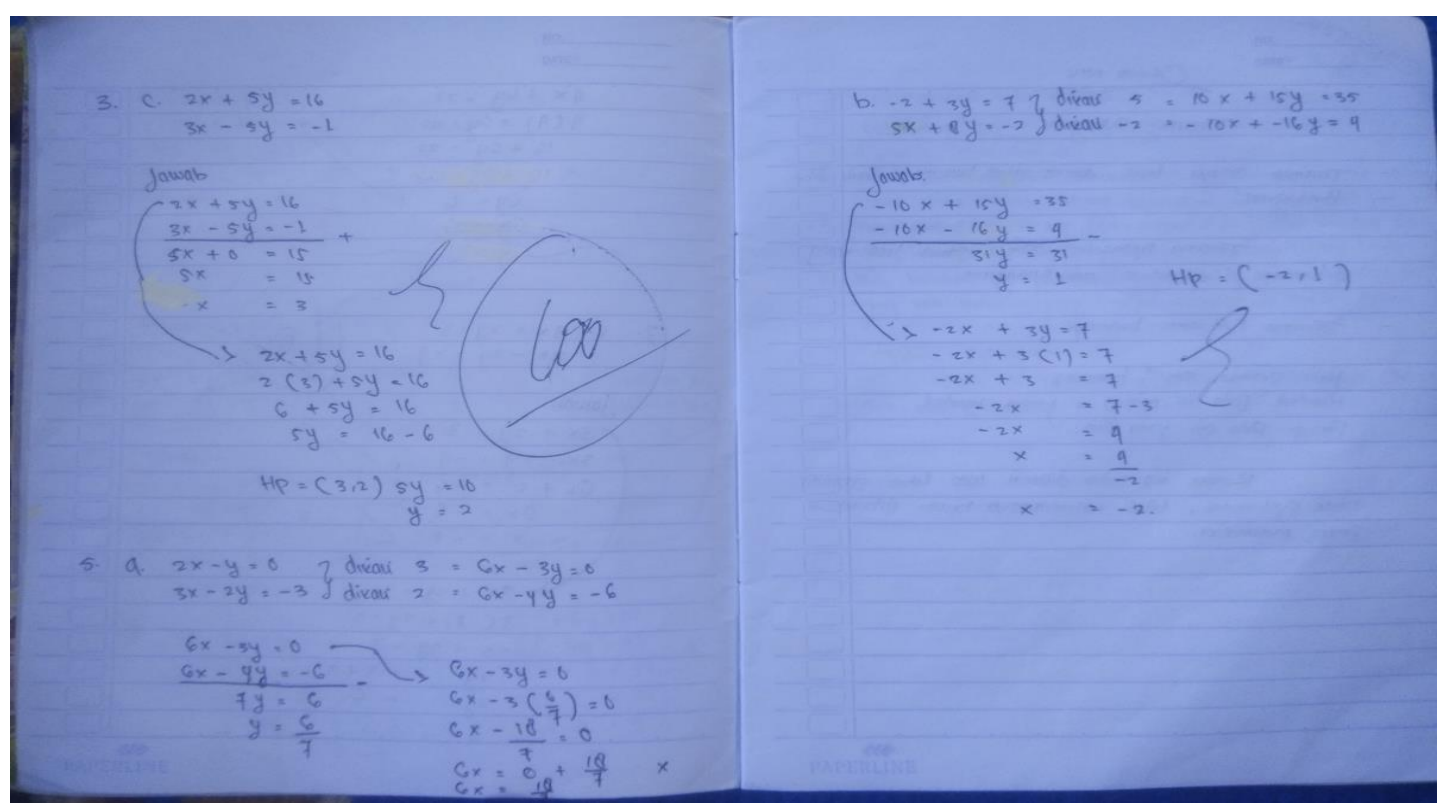

Gambar 6. Sesudah Memakai Aplikasi

Dari gambar hasil tugas harian salah satu siswa diatas kita dapat melihat perbahan hasil dari sebelum dengan sesudah menggunakan aplikasi zenius. Sebelum menggunakan aplikasi zenius sesuai dengan gambar 1.1 kita dapat melihat bahwasanya siswa mempunyai nilai 70. Dan pada gambar 1.2 yang merupakan hasil setelah menggunakan aplikasi zenius, kita dapat melihat nilai hasil tugas mandiri siswa meningkat dengan nilai 100. Dari sini kita sudah melihat perbandingan dan peningkatan hasil belajar siswa SMP Negeri 2 kampar Utara dengan bagus. Dengan hasil peningkatan ini, peneliti berpendapat bahwa aplikasi Zenius ini merupakan aplikasi yang dapat meningkatkan 
motivasi belajar siswa dengan fitur-fitur yang disajikan aplikasi Zenius. Walaupun hanya sedikit dari siswa yang merespon dan menggunakan aplikasi gratis ini. Tetapi dari sedikit responden ini dapat dilihat adanya perubahan motivasi pada siswa tersebut. Meskipun banyak kendala yang dialami peneliti saat melakukan penelitian secara online.

\section{KESIMPULAN}

Mewabahnya virus Corona membuat beberapa pemerintah daerah mulai mengambil sikap untuk meliburkan sekolah sebagai suatu upaya untuk mencegah sekaligus mengurangi penyebaran virus Corona. Kegiatan akademik selama masa ini banyak dilakukan melalui belajar dari rumah (study from home). Tak sedikit pula dari instansi pendidikan yang memberlakukan E-learning atau kelas online untuk melakukan proses belajar mengajar jarak jauh. Pada dasarnya E-learning merupakan suatu sistem atau konsep pendidikan yang memanfaatkan teknologi informasi dalam proses belajar mengajar. Menerapkan E-learning di tengah situasi virus Corona bukan saja bermanfaat untuk melindungi para siswa dari penyebaran virus Corona, melainkan menerapkan E-learning juga bisa membangun rasa percaya diri dan kemandirian dari para siswa. Akan tetapi tidak sedikit siswa atau pelajar tidak menyukai pembelajaran daring ini. Hal tersebut terjadi karena kurangnya kualitas penyajian materi yang diberikan guru melalui pembelajaran online ini. Dengan pembelajaran dari rumah atau daring ini, dari hasil peneliti, siswa-siswa kebanyakan mempunyai kendala dalam memahami materi pembalajaran. Kurangnya penyajian materi dan banyaknya tugas membuat siswa kurang termotivasi dalam mengikuti pembelajran khususnya belajar matematika. Walaupum demikian, setiap masalah yang dihadapi siswa pasti ada solusinya. Oleh sebab itu, peneliti mencari solusi dengan melakukan penelitian dengan mengunakan aplikasi garatis yaitu Zenius. Dengan aplikasi Zenius tersebut siswa akan disajikan video pembelajaran mengenai materi-materi yang akan dipelajari siswa. Tidak hanya video pembelajran matematika saja tetapi juga video pembelajran lainnya seperti IPA, IPS, dan Bahasa Inggris. Dengan aplikasi Zenius tersebut peneliti mendapatkan hasil bahwa siswa dapat lebih baik memahami materi dan mengerjakan tugas.

\section{UCAPAN TERIMA KASIH}

Terimakasih kami ucapkan kepada Bapak/Ibu Kepala Sekolah dan Guru-guru di SMP Negeri 2 Kampar Utara yang telah memberikan kesempatan kepada kami dalam melaksanakan penelitian. Terimakasih kepada siswa yang telah ikut berpartisipasi dalam melaksanakan penelitian ini.

\section{DAFTAR PUSTAKA}

Amri, Sofan. (2013). Pengembangan dan model pembelajaran dalam kurikulum 2013. Jakarta: Prestasi Pustaka Publisher.

Anni, catharina T, dkk. (2006). Psikologi Belajar. Semarang: Unnes Press. 
Penerapan E-Learning dengan Aplikasi Zenius untuk Meningkatkan Motivasi Belajar Siswa SMP Negeri 2 Kampar Utara, Nurfitriana, Zulfah

Cucu, Suhana. (2014). Konsep Strategi Pembelajaran. Bandung: PT Refika Aditama.

Putra, Y. M. (2018). Pengenalan E-learning. Modul Kuliah Sistem Informasi Managemen. Jakarta: FEB-Universitas Mercu Buana.

Nashar, H. (2004). Peranan Motivasi Kemampuan Awaldalam kegiatan pembelajaran, Cet 2, Delia Press, Jakarta

Zenius.net. (2019). 